\title{
Oxidation of the zinc-thiolate complex and uncoupling of endothelial nitric oxide synthase by peroxynitrite
}

\author{
Ming-Hui Zou, Chaomei Shi, and Richard A. Cohen \\ Vascular Biology Unit, Whitaker Cardiovascular Institute, Department of Medicine, Boston University School of Medicine, \\ Boston, Massachusetts, USA
}

Address correspondence to: Ming-Hui Zou, Vascular Biology Unit X708, Boston University School of Medicine, 650 Albany Street, Boston, Massachusetts 02118, USA. Phone: (617) 638-7114; Fax: (617) 638-7113; E-mail: mhzou@medicine.bu.edu.

Received for publication October 18, 2001, and accepted in revised form February 8, 2002.

Nitric oxide (NO) is produced by NO synthase (NOS) in many cells and plays important roles in the neuronal, muscular, cardiovascular, and immune systems. In various disease conditions, all three types of NOS (neuronal, inducible, and endothelial) are reported to generate oxidants through unknown mechanisms. We present here the first evidence that peroxynitrite $\left(\mathrm{ONOO}^{-}\right)$releases zinc from the zinc-thiolate cluster of endothelial NOS (eNOS) and presumably forms disulfide bonds between the monomers. As a result, disruption of the otherwise SDS-resistant eNOS dimers occurs under reducing conditions. eNOS catalytic activity is exquisitely sensitive to $\mathrm{ONOO}^{-}$, which decreases NO synthesis and increases superoxide anion $\left(\mathrm{O}_{2}^{--}\right)$production by the enzyme. The reducing cofactor tetrahydrobiopterin is not oxidized, nor does it prevent oxidation of eNOS by the same low concentrations of OONO-. Furthermore, eNOS derived from endothelial cells exposed to elevated glucose produces more $\mathrm{O}_{2}{ }^{-}$, and, like eNOS purified from diabetic LDL receptor-deficient mice, contains less zinc and fewer SDS-resistant dimers. Hence, eNOS exposure to oxidants including $\mathrm{ONOO}^{-}$causes increased enzymatic uncoupling and generation of $\mathrm{O}_{2}{ }^{-}$in diabetes, contributing further to endothelial cell oxidant stress. Regulation of the zinc-thiolate center of $\mathrm{NOS}^{-}$by $\mathrm{ONOO}^{-}$provides a novel mechanism for modulation of the enzyme function in disease.

\footnotetext{
This article was published online in advance of the print edition.

The date of publication is available from the JCI website, http://www.jci.org.

J. Clin. Invest. 109:817-826 (2002). DOI:10.1172/JCI200214442.
}

\section{Introduction}

Nitric oxide (NO) is an endogenous signaling molecule that is synthesized from L-arginine and $\mathrm{O}_{2}$ by a family of NO synthases (NOS's) that includes neuronal, inducible, and endothelial NOS (nNOS, iNOS, and eNOS, respectively) (1-8). NOS maintains two catalytic domains that consist of a C-terminal reductase where NADPH, FMN, and FAD bind, and an N-terminal oxygenase domain where heme, 5,6,7,8-tetrahydrobiopterin $\left(\mathrm{BH}_{4}\right)$, oxygen, and L-arginine bind (1-8). The catalytic mechanisms of NOS involve flavin-mediated electron transport from C-terminal-bound NADPH to the $\mathrm{N}$-terminal heme center, where oxygen is reduced and incorporated into the guanidine group of L-arginine, giving rise to $\mathrm{NO}$ and L-citrulline.

All three NOS's are dimeric enzymes comprised of two identical subunits, and NOS is catalytically active only in dimeric form (4-10). X-ray crystallography for all three isoforms of NOS shows a zinc thiolate $\left(\mathrm{ZnS}_{4}\right)$ cluster formed by a zinc ion coordinated in a tetrahedral conformation with pairs of symmetrically oriented and phylogenetically conserved cysteine residues at the dimer interface (4-12). Mutation within a $C\left(x_{4}\right) C$ motif prevents the binding of zinc, $\mathrm{BH}_{4}$, or L-arginine and eliminates enzyme activity (8-12), suggesting that stabilization of the dimer interface by the zinc-thiolate center is key for catalytic activity. Regulation of NOS subunit interactions could, therefore, provide a mechanism for modulation of enzyme activity in vivo.

Peroxynitrite $\left(\mathrm{ONOO}^{-}\right)$is a highly reactive oxidant formed by the reaction of $\mathrm{O}_{2}^{--}$and NO. It is formed in increased amounts during sepsis, inflammation, ischemia-reperfusion, and atherosclerosis $(13,14)$. There is evidence that $\mathrm{ONOO}^{-}$is formed by eNOS under pathological conditions (15-18). ONOO- oxidizes sulfhydryls, can nitrate and hydroxylate aromatic rings, and also oxidize lipids, proteins, and DNA. The reactions of $\mathrm{ONOO}^{-}$ are greatly facilitated by the presence of metal-iron centers or heme-thiolate clusters (19-21). Although zinc is not redox active in aqueous solution, it has the highest charge-to-atomic radius ratio of any element, and maintains partial cationic character even in tetracoordinate complexes such as zinc-thiolate clusters (22-25). Thus, zinc will attract anionic oxidants such as $\mathrm{ONOO}^{-}$, oxidizing the coordinated thiols in the process of releasing zinc and forming disulfide bonds (22-25). In the present study, we investigated whether or not a modification of the zinc-thiolate cluster by $\mathrm{ONOO}^{-}$ affects eNOS function in vitro and in vivo. We demonstrate for the first time that $\mathrm{ONOO}^{-}$disrupts the zincthiolate cluster of eNOS, resulting in uncoupling of the enzyme. Our findings in studies of recombinant eNOS were similar to those from studies using cultured bovine aortic endothelial cells exposed briefly to $\mathrm{ONOO}^{-}$or for prolonged periods to elevated 
glucose, or from studies of eNOS from diabetic mouse hearts and kidneys. Of note is the fact that, in contrast to the high sensitivity of the zincthiolate center to $\mathrm{ONOO}^{-}, \mathrm{BH}_{4}$ was oxidized only at 10 - to 100 -fold higher concentrations than those needed to disrupt the zinc-thiolate complex of eNOS, indicating that the principal mechanism of inactivation of the enzyme is likely to be oxidation of the zinc-thiolate center and loss of zinc.

\section{Methods}

Materials. Bovine aortic endothelial cells (BAECs) and cell culture media were obtained from Clonetics BioWhittaker Inc. (Walkersville, Maryland, USA). Bovine recombinant eNOS, 2-(N,N-diethylamino)diazenolate-2oxide, (DEA-NONOate) and 3-morpholinosydnonimine (SIN-1) were obtained from Cayman Chemical (Ann Arbor, Michigan, USA). Polyclonal and monoclonal antibodies against eNOS were obtained from Transduction Laboratories (San Diego, California, USA). $\mathrm{BH}_{4}, \mathrm{NADPH}$, and the NOS assay kit were purchased from CalbiochemNovabiochem Corp. (La Jolla, California, USA). 4-(2-pyridylazo)resorcinol disodium salt (PAR), hydrogen peroxide, nitrilotriacetic acid, 2-mercaptoethanol, calcium ionophore A23187, cytochrome $c$, polyethylene glycol-1 inked superoxide dismutase (SODPEG), catalase, and tetranitromethane (TNM) were obtained from Sigma Chemical Co. (St. Louis, Missouri, USA). Chelex 100 resin was purchased from Bio-Rad Laboratories Inc. (Hercules, California, USA). Monoclonal antibody against 3-nitrotyrosine was obtained from Upstate Biotechnology Inc. (Lake Placid, New York, USA). Zinc chloride came from Aldrich Chemical Co. (Milwaukee, Wisconsin, USA). Guanidine $\mathrm{HCl}$ was from ICN Biomedicals Inc. (Aurora, Ohio, USA). Tetrakis-(2-pyridylmethyl)ethylenediamine (TPEN) and Tris-(2-cyanoethyl)phosphine were obtained from Molecular Probes Inc. (Eugene, Oregon, USA). Other chemicals and organic solvents of the highest grade were obtained from Fisher Scientific Co. (Pittsburgh, Pennsylvania, USA).

eNOS purification. Bovine recombinant eNOS was isolated from SF9 cells and eNOS protein was purified from the whole cell lysates of BAECs or animal tissues. Purification of eNOS was performed using the method of Pollock et al. (26), with modification. Briefly, animal tissues or BAECs were prepared by homogenization in icecold buffer A $(50 \mathrm{mmol} / \mathrm{l}$ Tris- $\mathrm{HCl}, \mathrm{pH}$ 7.5 , supplemented with $1 \mathrm{mmol} / 1$ EDTA, $2 \mathrm{mmol} / 1$ 2-mercaptoethanol, $1 \mathrm{mmol} / \mathrm{l} \mathrm{PMSF}$, and $10 \mu \mathrm{g} / \mathrm{ml}$ each of the protease inhibitors pepstatin A, aprotinin, and leupeptin). After centrifugation for 1 hour at $150,000 \mathrm{~g}$ at $4^{\circ} \mathrm{C}$, each pellet was homogenized in a mixture of equal volumes of buffer $\mathrm{A}$ and buffer $\mathrm{B}(1 \mathrm{~mol} / \mathrm{K} \mathrm{KCl}$ and $10 \%$ [vol/vol] glycerol) and recentrifuged for 30 minutes at $150,000 \mathrm{~g}$ at $4^{\circ} \mathrm{C}$. The resulting pellet was homogenized in a mixture of equal volumes of buffer $\mathrm{A}$ and buffer C (1\% [wt/vol] sodium salt of deoxycholic acid), mixed at $4^{\circ} \mathrm{C}$ for 20 minutes, and then centrifuged at $150,000 \mathrm{~g}$ for $30 \mathrm{~min}$ utes at $4^{\circ} \mathrm{C}$. The supernatant was incubated overnight at $4^{\circ} \mathrm{C}$ with 20 mg (dry weight) of $2^{\prime}, 5^{\prime}$-ADPSepharose 4B (Amersham Pharmacia Biotech, Piscataway, New Jersey, USA) equilibrated in buffer C. ADPSepharose beads were collected by centrifugation and washed three times with buffer C. Then eNOS was eluted from ADP-Sepharose beads by mixing at $4^{\circ} \mathrm{C}$ for 1 hour with $20 \mathrm{mmol} / 1$ NADPH in $1 \mathrm{ml}$ of buffer C. Buffer exchange was accomplished by centrifugation at $1,500 \mathrm{~g}$ for 75 minutes at $4^{\circ} \mathrm{C}$ in a Microcon-30 microconcentrator (Millipore Corp., Bedford, Massachusetts, USA) with two volumes of buffer D $(50 \mathrm{mmol} / \mathrm{l}$ Tris$\mathrm{HCl}, \mathrm{pH} 7.5,150 \mathrm{mmol} / \mathrm{l} \mathrm{NaCl}, 10$ $\mathrm{mmol} / 12$-mercaptoethanol, $1 \mathrm{mmol} / \mathrm{l}$ magnesium acetate, $1 \mathrm{mmol} / \mathrm{l}$ imidazole, $2 \mathrm{mmol} / 1 \mathrm{CaCl}_{2}$, and $0.05 \%$ Triton $\mathrm{X}-100)$. The sample retentate was adjusted to $1.4 \mathrm{ml}$ total volume in a $1.5-\mathrm{ml}$ microfuge tube and mixed overnight at $4^{\circ} \mathrm{C}$ with $50 \mu \mathrm{l}$ of calmodulin-Sepharose affinity resin slurry (Amersham Pharmacia Biotech) that had been preequilibrated in buffer $D$. The beads were washed three times in buffer $\mathrm{D}$ and pelleted, after which the supernatant was removed and subjected to normal- or low-temperature SDS-PAGE and immunoblotting or zinc assay. The high purity of eNOS was achieved because eNOS was the only protein seen in SDS-PAGE when visualized with Coomassie blue staining (not shown).

Determination of the SDS-resistant eNOS dimers and monomers. SDS-resistant eNOS dimers and monomers were assayed using low-temperature SDSPAGE under reducing or nonreducing conditions, as described previously $(7,8)$ but with modifications. After treatment, the samples were added to fivefold Laemmli buffer $(0.32 \mathrm{~mol} / \mathrm{l}$ Tris-HCl, pH 6.8, $0.5 \mathrm{~mol} / \mathrm{l}$ glycine, $10 \%$ SDS, $50 \%$ glycerol, and $0.03 \%$ bromophenol blue), with reducing gel (with 2.5\% 2-mercaptoethanol) or nonreducing gel (without 2-mercaptoethanol), in order to test the possibility of dimer dissociation by reduction of disulfide bridges. Samples were subjected to SDS-PAGE on $6 \%$ gels, using the Mini-Protean II system from Bio-Rad Laboratories Inc. Gels and buffers were kept in an ice bath at $4^{\circ} \mathrm{C}$. The gels were blotted onto nitrocellulose for Western blots or standard Coomassie staining. The nitrocellulose membranes were incubated with a monoclonal antibody against eNOS (1:1,000; Transduction Laboratories Inc.) in 5\% fat-free milk for 2 hours at room temperature or overnight at $4^{\circ} \mathrm{C}$. The blot was further incubated with a second horseradish peroxidase-conjugated antibody against mouse or rabbit Ig G (each diluted 1:7,500; Promega Corp., Madison, Wisconsin, USA) for 45 minutes at room temperature. The eNOS dimer and monomer were visualized using the ECL chemiluminescence kit (Amersham Pharmacia Biotech) according to the manufacturer's instructions. Because the immunoreactivity of eNOS monomers was reduced compared with that of dimers, Coomassie stains were used for the determination of monomers and dimers of recombinant eNOS. Because of the low amount of protein, Western blots were used to evaluate eNOS monomers and dimers in experiments with cells and tissues. The intensity (area times density) of the individual bands of eNOS was quantitated by densitometry (GS-700 Imaging Densitometer; Bio-Rad Laboratories Inc.); background was subtracted from the 
calculated area. The results were calculated as percent change compared with the corresponding control band.

$\mathrm{ONOO}^{-}$synthesis. $\mathrm{ONOO}^{-}$was synthesized using a quenched-flow reaction as previously described $(19,20,27)$. The concentrations of $\mathrm{ONOO}^{-}$were determined spectrophotometrically in $0.1 \mathrm{M}$ $\mathrm{NaOH}\left(\varepsilon_{302}=1,670 \mathrm{M}^{-1} \mathrm{~s}^{-1}\right)$.

Treatment of eNOS and BAECs with $\mathrm{ONOO}^{-}$. Purified recombinant eNOS (4 $\mu \mathrm{g})$ was first diluted in $37 \mu \mathrm{l}$ of 100 $\mathrm{mmol} / \mathrm{l} \mathrm{Na} \mathrm{HPO}_{3}(\mathrm{pH} 7.4$ ) or $1 \mathrm{~mol} / \mathrm{l}$ Tris ( $\mathrm{pH}$ 7.4) as indicated, and then treated with $3 \mu \mathrm{l}$ of $\mathrm{ONOO}^{-}$at room temperature with vigorous mixing. The eNOS activities were immediately assayed after treatment with $\mathrm{ONOO}^{-}$ (within less than 10 minutes). Confluent BAECs in six-well plates were rinsed twice with PBS buffer ( $\mathrm{pH}$ 7.4), and then $950 \mu \mathrm{l}$ HEPES buffer $(100 \mathrm{mmol} / \mathrm{l}, \mathrm{pH}$ 7.4) was added. Fifty microliters of concentrated $\mathrm{ONOO}^{-}$in $0.1 \mathrm{~mol} / \mathrm{l} \mathrm{NaOH}$ was evenly but quickly added to plates in rapidly rotating orbital shakers at room temperature. There was no $\mathrm{pH}$ shift during treatment with $\mathrm{ONOO}^{-}$. Fifty microliters of $0.1 \mathrm{~mol} / 1 \mathrm{NaOH}$ or decomposed $\mathrm{ONOO}^{-}$were used as controls; $\mathrm{ONOO}^{-}$was first decomposed in $1 \mathrm{~mol} / \mathrm{l}$ Tris buffer ( $\mathrm{pH} 7.4$ ) and kept for 5 minutes or overnight.

Exposure of BAECs to $\mathrm{NO}$ and $\mathrm{O}_{2}-$. Confluent BAECs in six-well plates were rinsed twice with PBS buffer, and then $1 \mathrm{ml}$ PBS buffer ( $\mathrm{pH}$ 7.4) was added to each plate. The cells were exposed at $37^{\circ} \mathrm{C}$ to either DEA-NONOate (5 $\mathrm{mmol} / \mathrm{l}$ for 30 minutes) or SIN-1 (5 $\mathrm{mmol} / \mathrm{l}$ for 3 hours), or to $\mathrm{O}_{2}{ }^{-}$generated from $10 \mathrm{mU} / \mathrm{ml}$ xanthine oxidase in the presence of $0.1 \mathrm{mmol} / 1$ hypoxanthine for 30 minutes. At $37^{\circ} \mathrm{C}$ in PBS buffer, $\mathrm{pH}$ 7.4, DEA-NONOate has a half-life of 2.1 minutes and releases 1.5 moles of NO per mole of starting material during decomposition. DEANONOate at $1 \mathrm{mmol} / \mathrm{l}$ was shown to releas $2.87 \mu \mathrm{mol} / \mathrm{l} / \mathrm{min}$ in a period of 3 minutes (27). Xanthine oxidase at 10 $\mathrm{mU} / \mathrm{ml}$ with $0.1 \mathrm{mmol} / 1$ hypoxanthine was shown to generate $\mathrm{O}_{2}^{--}$at a rate of $5.1 \mu \mathrm{mol} / \mathrm{min} / \mathrm{ml}$ in the first 5 minutes, as determined by the SOD-inhibitable cytochrome $c$ reduction assay (27). At the end of the incubation, the cells were rinsed twice with PBS buffer ( $\mathrm{pH}$ 7.4) and used for further experiments.
Measurement of reduced and oxidized thiols in purified eNOS. After being treated with $\mathrm{ONOO}^{-}$or $\mathrm{NaOH}$, the eNOS protein $(4 \mu \mathrm{g})$ was added to $200 \mu \mathrm{l}$ of guanidine $\mathrm{HCl}(7 \mathrm{~mol} / \mathrm{l})$. The reduced and oxidized thiols were measured using a kit from Oxis Health Products Inc. (Portland, Oregon, USA), according to the manufacturer's instructions.

Determination of enzyme activity of $e N O S$. The NO synthesizing activity of eNOS was determined by quantifying the rate of the conversion of $\left[{ }^{3} \mathrm{H}\right] \mathrm{L}-$ arginine to $\left[{ }^{3} \mathrm{H}\right] \mathrm{L}$-citrulline with kits obtained from Calbiochem-Novabiochem Corp. according to the manufacturer's instructions. The activity of eNOS in tissues was determined by the presence or absence of calcium in the assay buffer. The NADPH-dependent reductase activity of eNOS was determined by measuring eNOS-dependent NADPH consumption in the presence or absence of L-arginine $(0.5 \mathrm{mmol} / \mathrm{l})$ or $\mathrm{BH}_{4}(10 \mu \mathrm{mol} / \mathrm{l})$. NADPH oxidation was determined spectrophotometrically at $340 \mathrm{~nm}$ against $\mathrm{Ca}^{2+} / \mathrm{cal}-$ modulin-deficient blanks, using a molar absorption coefficient of 6.34 $\mathrm{mmol}^{-1} \mathrm{~cm}^{-1}$. Cytochrome $c$ reductase activity was determined spectrophotometrically in the assay buffer in the presence of $80 \mu \mathrm{mol} / \mathrm{l}$ cytochrome $c$ $\left(\varepsilon_{550}=21 \mathrm{mmol}^{-1} \mathrm{~cm}^{-1}\right)(7-12)$. Heme content of recombinant eNOS was monitored spectrophotometrically $\left(\varepsilon_{396}=102 \mathrm{mmol}^{-1} \mathrm{~cm}^{-1}\right)(7-12)$.

Determination of zinc release. Release of zinc from purified eNOS, BAECs, or tissue homogenates was measured by the PAR assay as described by Crow and others $(9,11,22)$. All buffers used for zinc assay were pretreated with Chelex 100 to remove background $\mathrm{Zn}^{2+}$. The Zinc content of eNOS was assayed with $100 \mu \mathrm{mol} / 1 \mathrm{PAR}$ at $23^{\circ} \mathrm{C}$ in $1 \mathrm{ml}$ of Chelex 100-pretreated Tris-HCI buffer $(1 \mathrm{~mol} / \mathrm{l}, \mathrm{pH}$ 7.4) in a rapidly stirred cuvette. The formation of the $\mathrm{PAR}_{2} \mathrm{Zn}^{2+}$ complex was monitored at $500 \mathrm{~nm}$ until no further increase was seen, about 200 seconds. At the end of the assay, $1 \mathrm{mmol} / 1$ nitrilotriacetic acid was added to remove zinc from the $\mathrm{PAR}_{2} \mathrm{Zn}^{2+}$ complex. The decrease in absorbance at $500 \mathrm{~nm}$ was used to quantify the amount of zinc released. At a concentration of $1 \mathrm{mmol} / \mathrm{l}$, nitrilotriacetic acid selectively chelates zinc but not copper $(8,11)$. To determine the total zinc content of untreated eNOS, maximal zinc release was determined by diluting eNOS proteins in $200 \mu \mathrm{l}$ guanidine $\mathrm{HCl}(7 \mathrm{~mol} / \mathrm{l})$ that had been pretreated with Chelex 100 and then incubated for 30 minutes. The extinction coefficient for $\mathrm{PAR}_{2} \mathrm{Zn}^{2+}$ was determined experimentally to be 76.7 $\mathrm{mmol}^{-1} \mathrm{~cm}^{-1}$ using a known concentration of zinc chloride.

Spectrophotometric analysis of $\mathrm{BH}_{4} . \mathrm{BH}_{4}$ $(1 \mathrm{mmol} / \mathrm{l})$ was dissolved in $1 \mathrm{~mol} / \mathrm{l}$ Tris$\mathrm{HCl}$ buffer ( $\mathrm{pH}$ 7.5) that had previously been purged extensively with argon gas. $\mathrm{BH}_{4}$ (final concentration $12.5 \mu \mathrm{mol} / \mathrm{l}$ ) was maintained anaerobically on ice until used (within less than 1 hour). In control experiments in which the oxidation of $\mathrm{BH}_{4}$ solution induced by $\mathrm{ONOO}^{-}$was examined, $100 \mu \mathrm{l}$ of ONOO$^{-}$was added to $900 \mu \mathrm{l}$ of deoxygenated Tris buffer $(1 \mathrm{~mol} / 1, \mathrm{pH} 7.4)$ in 1 -ml sample cuvettes. Buffer containing $\mathrm{BH}_{4}$ was used in the reference cuvette (blank). Absorbance of $\mathrm{BH}_{4}$ at $297 \mathrm{~nm}$ was followed for 300 seconds at room temperature using a Genesys 5 spectrophotometer (Thermo Spectronic US, Rochester, New York, USA). The autooxidation of $\mathrm{BH}_{4}$ by atmospheric oxygen at room temperature during the 300 -second assay in deoxygenated Tris buffer ( $\mathrm{pH}$ 7.4) was undetectable under our assay conditions. The auto-oxidation of $\mathrm{BH}_{4}$ by ambient oxygen was detected as only $0.083 \mu \mathrm{mol} / \mathrm{l} / \mathrm{min}$ in the first hour of incubation on ice, indicating stability of $\mathrm{BH}_{4}$ under the conditions of the assay, and the high sensitivity of the assay to the oxidation of $\mathrm{BH}_{4}$.

Detection of $\mathrm{O}_{2-}^{-}$release in cultured endothelial cells. The release of $\mathrm{O}_{2}-$ from cultured BAECs was assayed by the SOD-inhibitable cytochrome $c$ reduction assay $\left(\varepsilon_{550}=21 \mathrm{mmol}^{-1} \mathrm{~cm}^{-1}\right)$, as described elsewhere (28-30).

Immunoprecipitation of prostacyclin synthase. Immunoprecipitation of prostacyclin synthase was performed as described previously $(28,29)$, using a polyclonal antibody against prostacyclin synthase (28). The immunoprecipitates were boiled for 5 minutes, separated by normal-temperature SDS-PAGE, and subjected to Western blotting. Tyrosine-nitrated prostacyclin synthase was detected by a monoclonal antibody against 3-nitrotyro- 

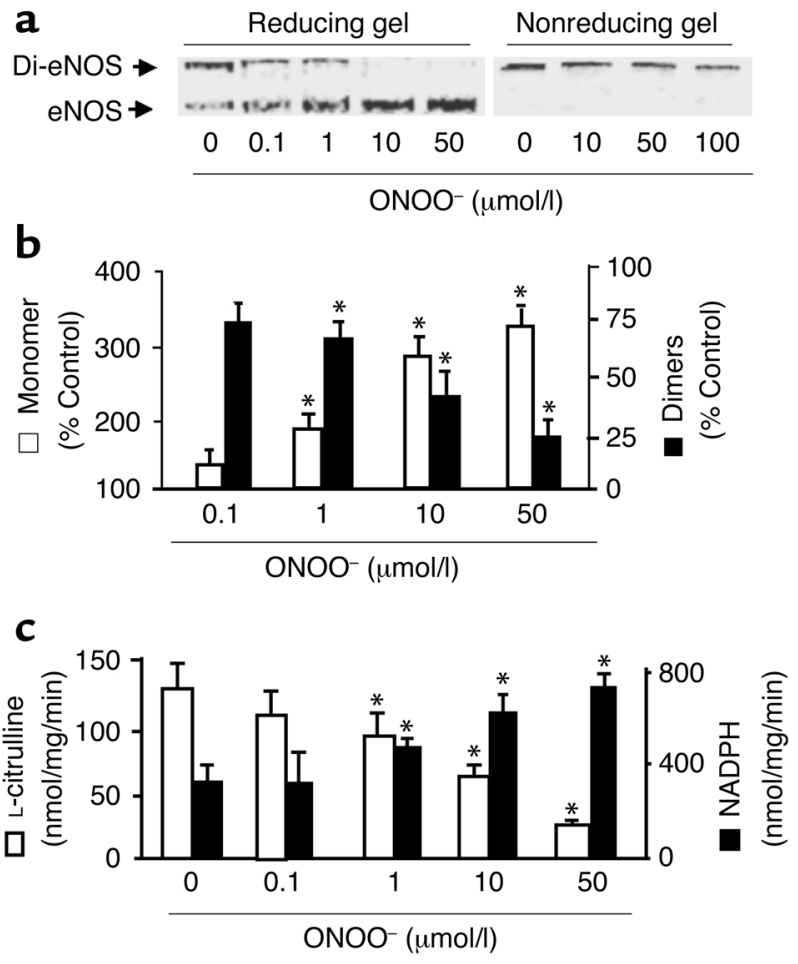

Figure 1

$\mathrm{ONOO}^{-}$dissociates SDS-resistant dimers and alters recombinant eNOS activity. Purified eNOS was treated with $\mathrm{ONOO}^{-}(0-100 \mu \mathrm{mol} / \mathrm{l})$, decomposed $\mathrm{ONOO}^{-}$, or $\mathrm{NaOH}$ vehicle $(100$ $\mathrm{mmol} / \mathrm{l}$ ) as described in Methods. Five minutes after treatment, eNOS dimers and monomers were separated by low-temperature SDS-PAGE (6\%) under reducing or nonreducing conditions. The proteins were visualized by Coomassie staining. (a) Representative blots of eNOS dimers and monomers in reducing (left) or nonreducing gels (right). (b) ONOO- dissociated eNOS dimers into monomers under reducing conditions. The intensity (area times density) of dimers and monomers was determined by densitometry as described in Methods. The results were expressed as percent change compared with untreated enzyme $\left(n=10,{ }^{*} P<0.05\right)$. (c) Inhibition by $\mathrm{ONOO}^{-}(0.1-50 \mu \mathrm{mol} / \mathrm{l})$ of the rate of eNOS-dependent L-citrulline formation $(n=12)$ was associated with an increase in NADPH oxidation $(n=14)$. L-citrulline formation and NADPH oxidation by purified recombinant eNOS were each assayed as described in Methods. ${ }^{*} P<0.01$. Di-eNOS, eNOS dimer; eNOS, eNOS monomer.

sine (1:1,000; Upstate Biotechnology Inc.) as described previously $(27,28)$.

Streptozotocin-induced diabetic LDLRKO mice. Male LDLR-KO mice were obtained from The Jackson Laboratory (Bar Harbor, Maine, USA). At 7 weeks of age, mice received five daily intraperitoneal injections of streptozotocin $(100 \mathrm{mg} / \mathrm{kg} /$ day $)$ or its carrier (citrate buffer, $\mathrm{pH} 4.5$ ) alone. Within 1 week, serum glucose increased stably to over $16.5 \mathrm{mmol} / \mathrm{l}$ in streptozotocintreated mice. Mice were euthanized at 15 weeks of age. Heart, liver, and kidneys were quickly removed and frozen for the assays reported here.

Quantification of aortic atherosclerotic lesion area. Atherosclerotic lesions were quantified by planimetry of oil red $\mathrm{O}$-stained lesions on the aortic intima
(31). Briefly, the entire thoracic and abdominal aorta was rinsed with cold PBS buffer, cut open longitudinally through its ventral side under a dissecting microscope, and immersed in oil red O $(60 \%$ solubilized in propylene glycol). An additional incision was made at the aortic arch along the dorsal side, from the aortic root to the left subclavian bifurcation, and the entire vessel was photographed. Quantification of stained lesion area was performed on the digitized images using Scion Image software (Scion Corp., Frederick, Maryland, USA).

\section{Results}

$\mathrm{ONOO}^{-}$dissociates SDS-resistant eNOS dimers of recombinant eNOS. Bovine recombinant eNOS was purified by sequential chromatography using $2^{\prime} 5^{\prime}$-ADP-Sepharose and calmodulinSepharose to apparent homogeneity, as judged by a single band in the gels stained with Coomassie blue (data not shown). We used low-temperature SDSPAGE to characterize the monomer and dimer of eNOS in reducing conditions (with added 2-mercaptoethanol) or nonreducing conditions. When purified recombinant eNOS was loaded after being boiled for 5 minutes, the expected $130-\mathrm{kDa}$ monomer was observed under reducing conditions (data not shown). However, if the protein was loaded onto the gel without previous boiling, two bands were observed, one of which comigrated with the denatured monomer in reducing gels. The higher-molecular-weight band corresponded to the SDS-resistant, $260-\mathrm{kDa}$ eNOS dimer. In nonreducing gels, eNOS migrated solely as a dimer (Figure 1a, right).

We first examined whether chemically synthesized $\mathrm{ONOO}^{-}$affects the SDSresistant eNOS dimers. Recombinant eNOS treated with up to $0.1 \mathrm{mmol} / 1$ $\mathrm{ONOO}^{-}$remained in dimer form in nonreducing gels (Figure 1a). Further increase in $\mathrm{ONOO}^{-}$(up to $1 \mathrm{mmol} / \mathrm{l}$ ) caused a slight decrease in the amount of dimer (data not shown), but the decrease in dimer did not result in an increase in eNOS monomers. However, reducing gel assays showed that low concentrations of $\mathrm{ONOO}^{-}$caused a concentration-dependent dissociation of eNOS dimers, resulting in an increase in eNOS monomers (Figure 1a). This indicates that $\mathrm{OONO}^{-}$formed disulfide bonds between eNOS monomers that were broken under reducing conditions. $\mathrm{ONOO}^{-}$at a concentration of $10 \mu \mathrm{mol} / \mathrm{l}$ disrupted $67 \% \pm 10 \%$ of the eNOS dimers, and $50 \mu \mathrm{mol} / 1 \mathrm{ONOO}^{-} \mathrm{com}^{-}$ pletely converted the dimers into eNOS monomers (Figure 1b). The effect of $\mathrm{ONOO}^{-}$was completed within seconds and was irreversible (data not shown). Neither $\mathrm{NaOH}$ nor decomposed $\mathrm{ONOO}^{-}$dissociated eNOS dimers (data not shown), excluding an effect of a $\mathrm{pH}$ shift or decomposed products of $\mathrm{ONOO}^{-}$. Interestingly, when eNOS was detected by Western blotting, ONOOwas shown to have decreased eNOS dimers, but a corresponding increase in eNOS monomers was not observed 
(data not shown). Since $\mathrm{ONOO}^{-}$affected neither eNOS protein transfer onto nitrocellulose membrane nor its staining with Coomassie blue, this discrepancy might suggest a conformational change that lowered the affinity of the antibody to oxidized eNOS.

It was of interest to investigate whether or not other oxidants $\left(\mathrm{O}_{2}{ }^{-}\right.$, $\mathrm{H}_{2} \mathrm{O}_{2}$, or $\mathrm{NO}$ ) mimic the effects of $\mathrm{ONOO}^{-}$. Neither $\mathrm{O}_{2}-{ }^{-}$(generated from $10 \mathrm{mU} / \mathrm{ml}$ xanthine oxidase and 0.1 $\mathrm{mmol} / \mathrm{l}$ hypoxanthine) nor $0.1 \mathrm{mmol} / \mathrm{l}$ $\mathrm{H}_{2} \mathrm{O}_{2}$ (30-minute incubation for each) affected the SDS-resistant eNOS dimers evaluated in reducing gels (data not shown). NO generated from DEA-NONOate $(5 \mathrm{mmol} / \mathrm{l})$ also did not dissociate eNOS dimers. However, SIN-1 $(5 \mathrm{mmol} / \mathrm{l})$, which simultaneously releases both $\mathrm{NO}$ and $\mathrm{O}_{2}^{-}$, which react to form $\mathrm{ONOO}^{-}$, caused a significant conversion of eNOS dimers to monomers under reducing conditions, similar to the results obtained using reagent $\mathrm{ONOO}^{-}$(data not shown).

Effect of $\mathrm{ONOO}^{-}$on recombinant eNOS activity. In the absence of L-arginine or $\mathrm{BH}_{4}$, recombinant eNOS did not form L-citrulline, but exhibited $\mathrm{Ca}^{2+} /$ calmodulin-dependent NADPH oxidase activity of $156 \pm 21$ $\mathrm{nmol} / \mathrm{mg} / \mathrm{min}$. The addition of exogenous L-arginine $(500 \mu \mathrm{mol} / \mathrm{l})$ and $\mathrm{BH}_{4}(10 \mu \mathrm{mol} / \mathrm{l})$ significantly increased both L-citrulline formation $(137 \pm 21 \mathrm{nmol} / \mathrm{mg} / \mathrm{min})$ and the rate of NADPH oxidation $(360 \pm 45$ $\mathrm{nmol} / \mathrm{mg} / \mathrm{min}$ ). L-nitroarginine methyl ester (L-NAME, $1 \mathrm{mmol} / \mathrm{l}$ ) completely abolished L-citrulline formation, but only partially inhibited $\mathrm{NADPH}$ oxidation, to $87 \pm 12$ $\mathrm{nmol} / \mathrm{mg} / \mathrm{min}(-76 \% \pm 7 \%)$.

$\mathrm{ONOO}^{-}$caused a concentrationdependent inhibition of L-citrulline formation with an $\mathrm{IC}_{50}$ of approximately $15 \mu \mathrm{mol} / 1$ (Figure 1c). Decomposed $\mathrm{ONOO}^{-}(1 \mathrm{mmol} / \mathrm{l})$ had no effect.

In contrast with its effect on L-citrulline formation, $\mathrm{ONOO}^{-}$significantly increased the $\mathrm{Ca}^{2+} /$ calmodulindependent NADPH oxidation by recombinant eNOS (Figure 1c). NADPH oxidation was increased to $713 \pm 64 \mathrm{nmol} / \mathrm{mg} / \mathrm{min}$ and $787 \pm 85$ $\mathrm{nmol} / \mathrm{mg} / \mathrm{min}$ in the samples treated with $10 \mu \mathrm{M}$ and $50 \mu \mathrm{M} \mathrm{ONOO}^{-}$, respectively. The heme content, as measured spectrophotometrically at $398 \mathrm{~nm}$, was not affected by $\mathrm{ONOO}^{-}(0.81 \pm 0.08$ vs. $0.83 \pm 0.11 \mathrm{~mol} / \mathrm{subunit})$. The calmodulin-dependent cytochrome $c$ reduction activity of eNOS was not affected by $\mathrm{ONOO}^{-}(2.97 \pm 0.47$ vs. $3.01 \pm 0.73$ $\mu \mathrm{mol} / \mathrm{mg} / \mathrm{min}$ ).

In line with their lack of effect on eNOS dimers, neither exogenous NO, $\mathrm{O}_{2}-$, nor $\mathrm{H}_{2} \mathrm{O}_{2}$ alone $(0.1 \mathrm{mmol} / \mathrm{l})$ affected L-citrulline formation or NADPH oxidation by eNOS (data not shown).

ONOO- oxidizes thiol(ate) groups and releases zinc from purified recombinant eNOS. Using purified recombinant eNOS, we next measured the thiol content of eNOS before and after exposure to $\mathrm{ONOO}^{-}$. $\mathrm{ONOO}^{-}(10$ $\mu \mathrm{mol} / \mathrm{l})$ decreased the thiol content of eNOS, as determined by Ellman's reagent, by $47 \% \pm 9 \%(n=10, P<0.01)$, indicating that $\mathrm{ONOO}^{-}$oxidized thiols. Decomposed $\mathrm{ONOO}^{-}$did not mimic this effect of $\mathrm{ONOO}^{-}$.
Because oxidation of zinc-thiolate clusters releases zinc (21-25), we next addressed whether or not $\mathrm{ONOO}^{-}$ released zinc from recombinant eNOS. Purified eNOS contained $0.46 \pm 0.07$ $\mathrm{mol} / \mathrm{subunit}$. Figure 2a shows concentration-dependent release of zinc from $\mathrm{ONOO}^{-}$-treated eNOS. $\mathrm{ONOO}^{-}(50$ $\mu \mathrm{mol} / \mathrm{l})$ depleted zinc from eNOS by $74 \% \pm 8 \%$. Neither $\mathrm{NO}$ donors nor $\mathrm{O}_{2}$ generated from xanthine oxidase affected eNOS zinc content (data not shown). Thiol oxidation and eNOS dimers. We next addressed whether oxidants other than $\mathrm{OONO}^{-}$oxidized free thiols but not the zinc-thiolate cluster of eNOS. $\mathrm{H}_{2} \mathrm{O}_{2}(0.1 \mathrm{mmol} / \mathrm{l})$, which lowered the reduced thiol content of eNOS $(-77 \% \pm 11 \% ; P<0.001, n=6)$, neither dissociated eNOS dimers nor caused zinc release from purified recombinant eNOS (data not shown). This indicates that oxidation of the zinc-thiolate cluster, but not free thi-

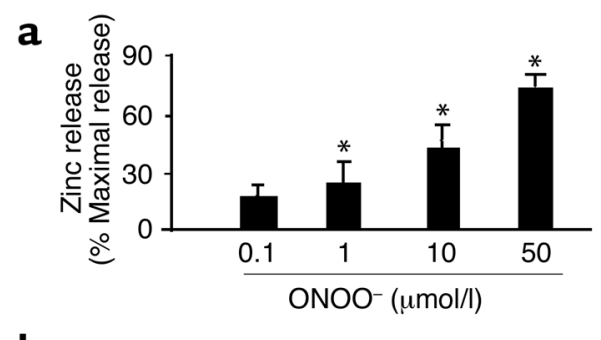

b
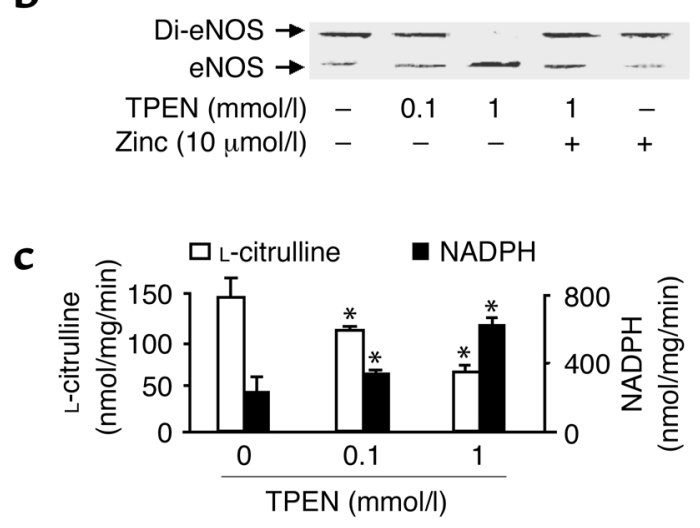

\section{Figure 2}

Monomer formation and activity of recombinant eNOS associated with zinc release. (a) $\mathrm{ONOO}^{-}(0.1-50 \mu \mathrm{mol} / \mathrm{l})$ stimulated zinc release from purified eNOS $\left(n=9,{ }^{*} P<0.01\right)$. Zinc was assayed as described in Methods and was expressed as percentage of maximal zinc release from eNOS diluted in $7 \mathrm{~mol} / \mathrm{I}$ guanidine $\mathrm{HCl}$. (b) Dissociation of eNOS dimers by zinc chelator TPEN. Purified eNOS was exposed to TPEN ( 0.1 or $1 \mathrm{mmol} / \mathrm{l}$ ) or methanol (control) in the presence or absence of exogenous zinc at room temperature for 30 minutes in 0.1 $\mathrm{M}$ HEPES buffer, $\mathrm{pH}$ 7.5. eNOS protein was subjected to low-temperature SDS-PAGE under reducing conditions, and the protein was visualized by Coomassie staining. Blot shown is representative of four independent experiments. (c) The effect of TPEN on eNOS function. The activity of eNOS treated with TPEN was assayed as described in Methods. The figure represents results obtained in six independent assays $\left(n=6,{ }^{*} P<0.05\right)$. 


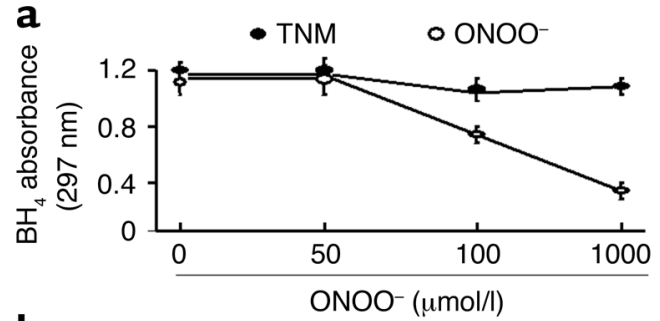

b

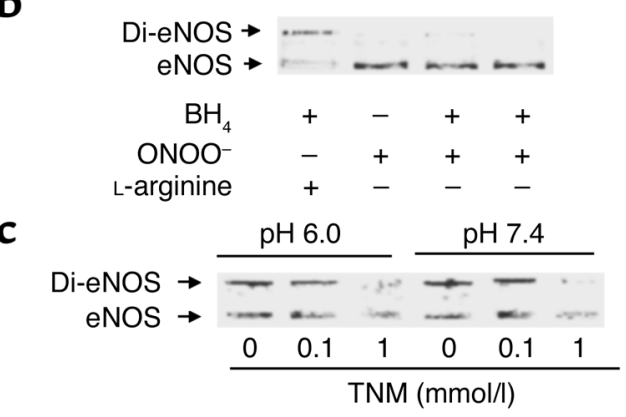

Figure 3

Comparison of $\mathrm{ONOO}^{-}$reactivity with the zinc-thiolate cluster of recombinant eNOS and its cofactor, $\mathrm{BH}_{4}$. (a) $\mathrm{BH}_{4}$ is oxidized by $\mathrm{ONOO}^{-}$but not by tetranitromethane (TNM). Note that $50 \mu \mathrm{mol} / / \mathrm{ONOO}^{-}$, which nearly completely dissociated eNOS dimers in low-temperature SDS-PAGE under reducing conditions, did not cause detectable oxidation of $\mathrm{BH}_{4}$. These results represent 15 assays in three independent experiments. (b) Effects of $\mathrm{BH}_{4}$ and/or L-arginine on $\mathrm{ONOO}^{-}$-induced dissociation of eNOS. $\mathrm{BH}_{4}(100 \mu \mathrm{mmol} / \mathrm{l})$ and L-arginine $(1 \mathrm{mmol} / \mathrm{l})$ were added to purified eNOS 10 minutes before addition of ONOO- ${ }^{-}$. Blot shown is representative of three independent experiments. (c) Representative blot of three independent experiments showing that TNM, which did not oxidize $\mathrm{BH}_{4}$, results in dissociation of eNOS dimer into monomer under reducing conditions. Purified eNOS was exposed to TNM $(0.1$ or $1 \mathrm{mmol} / \mathrm{l})$ or vehicle containing DMSO at room temperature for 30 minutes. eNOS dimer and monomer were assayed by low-temperature SDS-PAGE and visualized by Coomassie staining.

ols, is important for disruption of eNOS dimers. This result was further supported by the fact that both $5,5^{\prime}$ dithiobis(2-nitrobenzoic acid) (1 $\mathrm{mmol} / \mathrm{l})$ and $n$-ethylmaleimide (1 $\mathrm{mmol} / \mathrm{l}$ ), which oxidize free thiols but not the zinc-thiolate cluster, failed to disrupt eNOS dimers (data not shown). In contrast, hypochlorite (50 $\mu \mathrm{mol} / \mathrm{l}$ in a 30 -minute incubation), like $\mathrm{ONOO}^{-}$, which attacks both free thiols and zinc-thiolate clusters (22), dissociated eNOS dimers under reducing conditions (data not shown). Taken together, all these results show that $\mathrm{ONOO}^{-}$, which oxidizes the zincthiolate cluster in addition to free thiols, causes release of zinc and consequently cleaves dimers into monomers under reducing conditions.

Effect of the zinc chelator TPEN on recombinant eNOS dimers and activity. We evaluated the effect of TPEN, a selective zinc-chelating agent (32), to determine whether the chelation of zinc mimicked the effect of $\mathrm{ONOO}^{-}$.
Exposure of recombinant eNOS to TPEN $(0.1 \mathrm{mmol} / \mathrm{l}$ or $1 \mathrm{mmol} / \mathrm{l}$ for 30 minutes) converted eNOS dimers into monomers under reducing conditions (Figure 2b). The effect of TPEN was partially blocked by exogenous zinc (Figure $2 \mathrm{~b}$ ), but not by $\mathrm{Mg}^{2+}$ or $\mathrm{Cu}^{2+}$ (data not shown).

TPEN, like $\mathrm{ONOO}^{-}$, inhibited NO synthesis and enhanced NADPH oxidation by recombinant eNOS (Figure $2 \mathrm{c})$. The uncoupling of electron transfer from NADPH to heme also occurs in mutated eNOS that lacks the zincthiolate cluster (7), suggesting that a structural change caused by the removal of zinc is responsible for eNOS uncoupling. Therefore, the accelerated NADPH oxidation might result in a direct reduction of oxygen by flavin proteins, forming $\mathrm{O}_{2}-{ }^{-}(33$, 34). Since zinc chelation should not oxidize thiols to disulfide directly, the formation of disulfide bonds in TPEN-treated eNOS might be explained by the fact that TPEN has
SOD-like activity $(35,36)$ that could convert the $\mathrm{O}_{2}^{--}$generated by the uncoupled eNOS into $\mathrm{H}_{2} \mathrm{O}_{2}$, which in turn would oxidize the thiols.

Effects of exogenous L-arginine and $\mathrm{BH}_{4}$ on the dimers of recombinant eNOS treated with $\mathrm{ONOO}^{-}$. Endothelial dysfunction in various disease conditions, including hypertension, hypercholesterolemia, and diabetes, is associated with increased $\mathrm{O}_{2}-$ generation by eNOS and production of $\mathrm{ONOO}^{-}(17,37)$. Because supplementing with $\mathrm{BH}_{4}$ improves eNOS function under these conditions, it has been suggested that $\mathrm{BH}_{4}$ oxidation accounts for eNOS dysfunction $(15-17,37)$. Therefore, we determined whether or not $\mathrm{ONOO}^{-}$, at the concentrations at which it uncouples eNOS, could oxidize $\mathrm{BH}_{4}$. ONOO$^{-}(50 \mu \mathrm{mmol} / \mathrm{l})$, which nearly completely dissociated eNOS dimers, did not cause measurable oxidation of $\mathrm{BH}_{4}$ (Figure 3a). ONOO- did oxidize $\mathrm{BH}_{4}$ with an $\mathrm{EC}_{50}$ of approximately $100 \mu \mathrm{mol} / \mathrm{l}$, but this concentration is 10- to 100-fold higher than the concentration required to release zinc and dissociate eNOS dimers.

We also addressed whether or not $\mathrm{BH}_{4}$ prevented or reversed the dissociation of eNOS dimers triggered by $\mathrm{ONOO}^{-}$. High concentrations of $\mathrm{BH}_{4} \quad(0.1$ $\mathrm{mmol} / \mathrm{l})$, L-arginine $(1 \mathrm{mmol} / \mathrm{l})$, or both did not prevent dissociation of eNOS dimers when they were present during exposure of eNOS to $\mathrm{ONOO}^{-}$(Figure $3 b$ ). Because $\mathrm{BH}_{4}$, in more than 5,000fold excess over eNOS, did not prevent eNOS dimer dissociation, it is likely that oxidation of the zinc-thiolate cluster of eNOS, instead of $\mathrm{BH}_{4}$ oxidation, constitutes the primary mechanism by which $\mathrm{ONOO}^{-}$uncouples eNOS.

These results were further supported by experiments with tetranitromethane (TNM). TNM, a nitrating and oxidizing agent, did not oxidize $\mathrm{BH}_{4}$ (Figure 3a). However, like $\mathrm{ONOO}^{-}$, TNM effectively dissociated eNOS dimers (Figure 3c). TNM caused a similar disruption of eNOS dimers at both $\mathrm{pH} 7.4$ and $\mathrm{pH} 6.0$ (Figure 3c), indicating that oxidation of thiol(ate) clusters, rather than tyrosine nitration (which is caused by TNM only at pH 7.4) (38), is responsible for dissociation of eNOS dimers. Furthermore, eNOS treated with $\mathrm{ONOO}^{-}$(up to $0.1 \mathrm{mmol} / \mathrm{l}$ ) did 
not cross-react with antibodies against 3-nitrotyrosine (data not shown), nor did the $\mathrm{ONOO}^{-}$-treated eNOS shown to contain detectable amounts of 3-nitrotyrosine in analysis by HPLC coupled to UV and electrochemical detection (data not shown).

Effect of $\mathrm{ONOO}^{-}$and TPEN on eNOS dimers and activity in BAECs. Exogenous glutathione $(10 \mathrm{mmol} / \mathrm{l}$, one estimate of the amount of reduced thiols in most living cells) did not prevent $\mathrm{ONOO}^{-}$mediated disruption of recombinant eNOS dimers (data not shown). This indicates a highly selective action of $\mathrm{ONOO}^{-}$on the zinc-thiolate center of eNOS from which cells might not be protected. Confluent BAECs were treated with exogenous $\mathrm{ONOO}^{-}$, and as was seen with recombinant eNOS, ONOOcaused a concentration-dependent dissociation of eNOS dimers when evaluated in reducing gels (Figure 4, a and b) but not in nonreducing gels (data not shown). SIN-1 (5 mM) treatment of cells mimicked the effect of exogenous $\mathrm{ONOO}^{-}$(Figure 4, a and b). Neither L-arginine $(0.5 \mathrm{mmol} / \mathrm{l})$ nor $\mathrm{BH}_{4}(100$ $\mu \mathrm{mol} / \mathrm{l})$ prevented or restored the disruption of eNOS dimers in BAECs caused by $\mathrm{ONOO}^{-}$(data not shown).

$\mathrm{ONOO}^{-}$also caused a concentrationdependent increase in release of $\mathrm{O}_{2}{ }^{-}$in BAECs stimulated by the calcium ionophore A23187 (Figure 4b). The increase in $\mathrm{O}_{2}^{--}$was associated with increased eNOS dimer dissociation in $\mathrm{ONOO}^{-}$-treated cells when evaluated in reducing gels (Figure $4 \mathrm{~b}$ ). L-NAME, a selective blocker of eNOS activity, but not D-NAME, abolished the increased release of $\mathrm{O}_{2}$-- $^{-}$from $\mathrm{ONOO}^{-}$-treated cells. Neither oxypurinol $(10 \mu \mathrm{mol} / \mathrm{l})$, a potent inhibitor of xanthine oxidase, nor the mitochondrial respiration inhibitors antimycin $(10 \mu \mathrm{mol} / \mathrm{l})$ or rotenone $(10 \mu \mathrm{mol} / \mathrm{l})$ inhibited $\mathrm{O}_{2}{ }^{-}$ release upregulated by $\mathrm{ONOO}^{-}$(Figure 4c). Chelation of zinc in BAECs with TPEN (0.1 and $1 \mathrm{mmol} / \mathrm{l})$ increased $\mathrm{O}_{2}{ }^{-}$ release and decreased L-citrulline production by the cells to levels similar to those of cells treated with $50 \mu \mathrm{mol} / 1$ $\mathrm{ONOO}^{-}$(data not shown).

Dissociation of eNOS dimers in BAECs exposed to bigh glucose: evidence of $\mathrm{ONOO}^{-}$induced eNOS dysfunction. Increased protein expression of eNOS associated with increased $\mathrm{O}_{2}^{--}$and $\mathrm{ONOO}^{-}$has been demonstrated in cultured endothelial cells $(39,40)$ and in diabetic patients (41). In addition, there is indirect evidence for dysfunctional, uncoupled eNOS in experimental (42, $43)$ and clinical studies $(44,45)$ showing that the administration of $\mathrm{BH}_{4}$ improved endothelial dysfunction in diabetes, despite the fact that the levels of $\mathrm{BH}_{4}$ before treatment may be normal $(42,43)$. Therefore, we determined whether $\mathrm{ONOO}^{-}$induced by high glucose caused eNOS uncoupling in cultured BAECs. BAECs were exposed to normal glucose $(5 \mathrm{mmol} / \mathrm{l})$, high glucose $(30 \mathrm{mmol} / \mathrm{l})$, or L-glucose (5 $\mathrm{mmol} / \mathrm{l}$ D-glucose plus $25 \mathrm{mmol} / \mathrm{l}$
L-glucose). High glucose exposure, like $\mathrm{ONOO}^{-}$, significantly dissociated eNOS dimers into monomers under reducing conditions (Figure 5a). Exposure of the cells to L-glucose did not affect eNOS dimers (data not shown). A role for $\mathrm{ONOO}^{-}$is suggested by the fact that both SOD-PEG and L-NAME blocked the high glucose-induced decrease in eNOS dimers observed in BAECs exposed to elevated glucose (Figure 5b). It is also notable that SODPEG, which is cell-permeable and therefore should prevent formation of intracellular $\mathrm{ONOO}^{-}$, decreased the amount of eNOS monomer in BAECs grown in normal glucose, suggesting that eNOS a
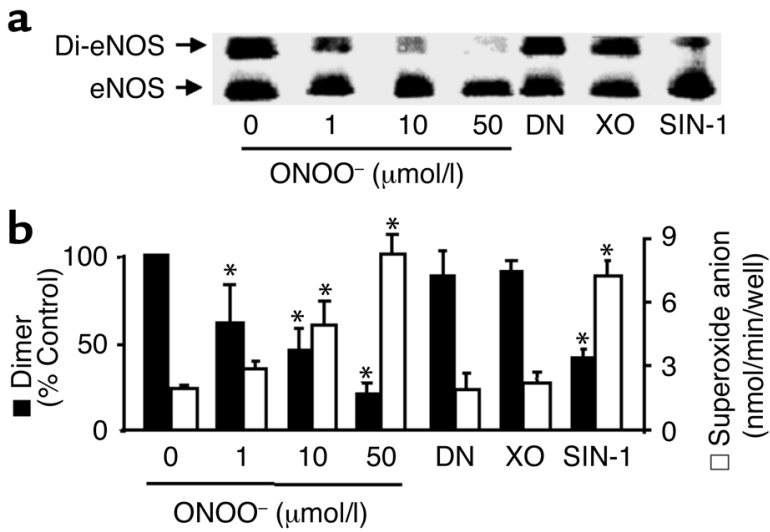

c

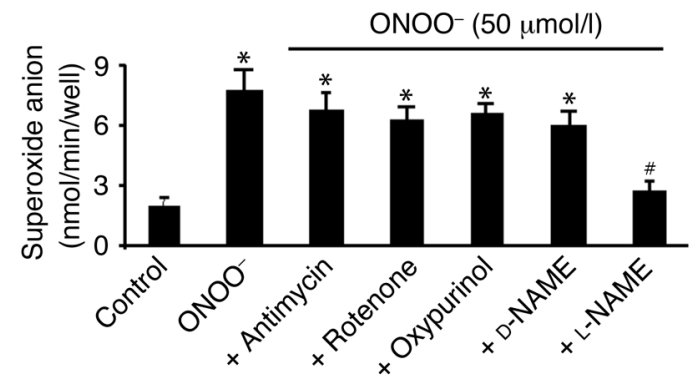

\section{Figure 4}

$\mathrm{ONOO}^{-}$dissociates eNOS dimers and triggers $\mathrm{O}_{2} \cdot-$ release in cultured BAECs. (a) ONOO- $(1-50$ $\mu \mathrm{mol} / \mathrm{l})$ increased dissociation of eNOS dimers in intact BAECs. The cells were treated with $\mathrm{ONOO}^{-}$as described in Methods, and eNOS dimers and monomers were separated by lowtemperature SDS-PAGE under reducing conditions. The eNOS protein was blotted onto nitrocellulose membranes and detected with a monoclonal antibody as described in Methods. Blot shown is representative of six independent experiments. (b) $\mathrm{ONOO}^{-}$and $\mathrm{SIN}-1$ decreased eNOS dimer but increased $\mathrm{O}_{2}^{-}$release in intact BAECs. Confluent BAECs were treated with $\mathrm{ONOO}^{-}$ (50 mmol/I), SIN-1 (5 mmol/I), DEA-NONOate (DN; $5 \mathrm{mmol} / \mathrm{I})$, or $\mathrm{O}_{2} \cdot{ }^{-}$generated from 10 $\mathrm{mU} / \mathrm{ml}$ xanthine oxidase in the presence of $0.1 \mathrm{mmol} / \mathrm{l}$ hypoxanthine $(\mathrm{XO})$. The cells were rinsed twice with $2 \mathrm{ml} \mathrm{PBS}$ buffer ( $\mathrm{pH}$ 7.4) and then exposed to calcium ionophore A23187 (10 $\mu \mathrm{mol} / \mathrm{I}$ ) for 2 hours. The amount of A23187-stimulated $\mathrm{O}_{2}$ - $^{-}$was measured by the SODinhibitable cytochrome $c$ reduction assay as described in Methods $\left(n=6\right.$ or $\left.8,{ }^{*} P<0.05\right)$. (c) eNOS-dependent $\mathrm{O}_{2}{ }^{-}$release in BAECs treated with $\mathrm{ONOO}^{-}$. Antimycin $(10 \mu \mathrm{mol} / \mathrm{l})$, rotenone $(10 \mu \mathrm{mol} / \mathrm{l})$, oxypurinol $(10 \mu \mathrm{mol} / \mathrm{I})$, D-NAME $(1 \mathrm{mmol} / \mathrm{l})$, or L-NAME $(1 \mathrm{mmol} / \mathrm{l})$ was added 10 minutes after treating BAECs with $\mathrm{ONOO}^{-}$and 10 minutes before the addition of A23187 $\left(n=10 ;{ }^{*} P<0.05\right.$ compared with untreated cells). The increase in $\mathrm{O}_{2}{ }^{-}$measured in cells exposed to $\mathrm{ONOO}^{-}$was prevented by L-NAME $\left(1 \mathrm{mmol} / \mathrm{l} ; n=8,{ }^{\sharp} P<0.01\right)$. 


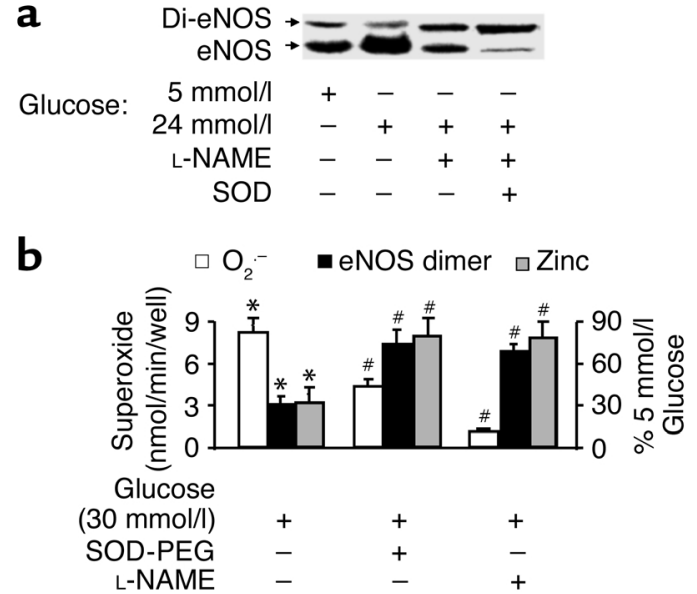

c

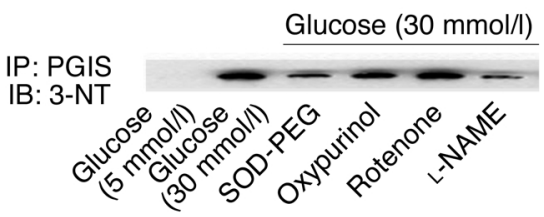

\begin{abstract}
Figure 5
Increased monomers and decreased zinc content in eNOS derived from BAECs exposed to high glucose are associated with increased $\mathrm{O}_{2} \cdot-$ and $\mathrm{ONOO}^{-}$. (a) Increased eNOS monomers in cells exposed to high glucose. Confluent BAECs were exposed to control $(5 \mathrm{mmol} / \mathrm{l}$ D-glucose) or high glucose $(30 \mathrm{mmol} / \mathrm{l})$ for 3 days. The eNOS protein was separated by low-temperature SDS-PAGE under reducing conditions, blotted, and detected with a monoclonal antibody. Blot shown is representative of results from eight independent experiments. (b) Increased eNOS monomer and correlated $\mathrm{O}_{2}{ }^{-}$release are associated with decreased zinc content in eNOS from cells exposed to high glucose $(n=10, \# P<0.05)$. The zinc content of eNOS from cells incubated in elevated glucose was assayed as described in Methods and expressed as a percentage of that in control cells exposed to $5 \mathrm{mmol} / \mathrm{l}$ glucose. Of note, both L-NAME $(1 \mathrm{mmol} / \mathrm{l})$ and SOD-PEG $(500 \mathrm{U} / \mathrm{ml})$ prevented high glucose-induced dissociation of eNOS dimers $\left(n=8,{ }^{*} P<0.01\right)$, zinc loss $\left(n=5,{ }^{*} P<0.01\right)$, and $\mathrm{O}_{2} \cdot{ }^{-}$release ( $n=6$, ${ }^{P} P<0.05$ compared with cells exposed to high glucose alone). (c) eNOS-dependent tyrosine nitration of prostacyclin synthase (PGIS) in cells exposed to high glucose. PGIS was immunoprecipitated with a polyclonal antibody against PGIS $(4 \mu \mathrm{g} / \mathrm{ml})$. The nitrated PGIS was detected with a monoclonal antibody against 3-nitrotyrosine (3-NT) $(1: 1,000$; Upstate Biotechnology Inc.). Of note, SOD-PEG $(500 \mathrm{U} / \mathrm{ml})$ or L-NAME $(1 \mathrm{mmol} / \mathrm{l})$, but not oxypurinol $(10 \mu \mathrm{mol} / \mathrm{I})$ or rotenone $(10 \mu \mathrm{mol} / \mathrm{I})$, prevented the nitration of PGIS. IP, immunoprecipitation; IB, immunoblot; PGIS, prostacyclin synthase. Blot shown is representative of three independent experiments.
\end{abstract}

is normally partially oxidized by $\mathrm{ONOO}^{-}$in cultured BAECs (Figure 5 , a and $b$ ). Of note, the effects of SOD-PEG were mimicked by the cell-permeable SOD mimic MnTMPyP $(10 \mu \mathrm{mol} / \mathrm{l})$ and by the $\mathrm{ONOO}^{-}$scavenger MnTBAP $(10 \mu \mathrm{mol} / \mathrm{l}$, data not shown).

The zinc content of eNOS purified from cells exposed to high glucose was significantly decreased compared with that from cells exposed to normal glucose (Figure 5b). SOD-PEG and L-NAME each prevented zinc loss from eNOS triggered by high glucose exposure, implying that $\mathrm{ONOO}^{-}$ causes zinc loss from eNOS.
We next addressed whether dysfunctional eNOS contributes to oxidative damage in cells exposed to high glucose. The increase in tyrosine nitration of prostacyclin synthase in BAECs exposed to high glucose was prevented by L-NAME and by SOD-PEG, suggesting that $\mathrm{ONOO}^{-}$derived from eNOS is responsible for tyrosine nitration (Figure 5c).

Oxidation of eNOS in diabetic $L D L R-K O$ mice. We next determined if dysfunction of eNOS in diabetes in vivo was attributable to oxidation of the zinc-thiol(ate) complex. Six-week-old LDLR-KO mice were made diabetic by injection of streptozotocin. At 15 weeks of age, streptozotocin-treated mice had significantly higher serum glucose (448 \pm 25 vs. $119 \pm 7 \mathrm{mg} / \mathrm{dl}$; $P<0.001 ; n=7$ per group) and serum cholesterol levels $(278 \pm 17$ vs. $644 \pm 87$ $\mathrm{mg} / \mathrm{dl} ; P<0.01)$ than did control animals. The body weights of diabetic animals were significantly lower than those of controls ( $15.6 \pm 3$ vs. $19.1 \pm 1 \mathrm{~g}$; $P<0.001)$. Aortic atherosclerotic lesion area in the streptozotocin-induced diabetic mice was significantly increased compared with that in nondiabetic animals, at $(897 \pm 107) \times 10^{3} \mu \mathrm{m}^{2}$ vs. $(201 \pm 51) \times 10^{3} \mu \mathrm{m}^{2} ; P<0.001$.

Increased amounts of eNOS protein were detected by Western blotting, after boiling under reducing conditions, in homogenates of the heart, kidneys, and liver of the diabetic LDLR-KO mice compared with homogenates from normoglycemic LDL-KO mice (Figure 6a). In order to determine whether dysfunction of eNOS occurs in the tissues of these diabetic atherosclerotic mice, tissue eNOS was purified and assayed for dimers and monomers, zinc content, and activity. After purification, it was apparent that the increased eNOS observed in the homogenate was primarily represented by an increase in eNOS monomers, because the amount of SDS-resistant eNOS dimer was significantly decreased (Figure 6, b and c). Despite the fact that increased amounts of eNOS protein were present in the tissues of the diabetic mice, the zinc content of eNOS purified from the heart and kidneys was significantly decreased, whereas that of the liver was not affected (Figure 6c). The decrease in eNOS dimers and zinc content was paralleled by significantly decreased L-citrulline formation in the diabetic LDLR-KO mice (Figure 6c).

\section{Discussion}

To our knowledge, the data presented here are the first evidence that $\mathrm{ONOO}^{-}$, an NO-derived oxidant, releases zinc from the zinc-thiolate cluster of eNOS and forms disulfide bonds between the monomers. As a result, disruption of SDS-resistant eNOS dimers occurs in reducing gels. The catalytic activities of recombinant $\mathrm{eNOS}$ are exquisitely sensitive to uncoupling by $\mathrm{ONOO}^{-}$, 
decreasing NO synthesis and increasing $\mathrm{O}_{2}$-- $^{-}$production by the enzyme. Furthermore, eNOS both in endothelial cells exposed to elevated glucose and in diabetic LDLR-KO mouse tissues showed loss of zinc, decreased SDSresistant dimers, and uncoupling of enzymatic activity, indicating the significance of this process under in vivo conditions in diabetes.

There are several lines of evidence that are consistent with the hypothesis that loss of zinc underlies the uncoupling of eNOS catalytic activity. First, $\mathrm{ONOO}^{-}$or SIN-1, but not decomposed $\mathrm{ONOO}^{-}, \mathrm{H}_{2} \mathrm{O}_{2}$, $\mathrm{NO}$, or $\mathrm{O}_{2}{ }^{--}$, promoted the release of zinc from the zinc-thiolate cluster of eNOS. Second, the effects of $\mathrm{ONOO}^{-}$were mimicked by the zinc chelator TPEN. Third, the release of zinc was accompanied by oxidation of the thiols and formation of intermolecular disulfide bonds. This is supported by the fact that eNOS dimers treated with $\mathrm{ONOO}^{-}$ were dissociable under reducing conditions. Fourth, the crystal structures of the heme domain of inducible NOS (iNOS) in zinc-free and zinc-bound states have been described (6), and in the zinc-free structure, these same two symmetrically positioned cysteine pairs found in eNOS form disulfide bonds, indicating that disulfide bridges can be formed after loss of zinc (6). Because iNOS and nNOS often function under oxidative conditions such as inflammation where they may be uncoupled (46-48), it is conceivable that $\mathrm{ONOO}^{-}$also causes zinc loss from both iNOS and nNOS by a similar mechanism. Finally, the fact that high concentrations of exogenous reduced thiols did not block the oxidation by $\mathrm{ONOO}^{-}$of zinc-thiolate complexes in eNOS dimer suggests that the zincthiolate complex rather than free thiols in eNOS is the primary target for $\mathrm{ONOO}^{-}$. This is emphasized by experiments in which $\mathrm{H}_{2} \mathrm{O}_{2}$ oxidized free thiols without affecting eNOS dimer or zinc content.

The zinc-thiolate cluster represents a selective target for $\mathrm{ONOO}^{-}$. The reaction of $\mathrm{ONOO}^{-}$with zinc-thiolate clusters is at least 1,000 times faster than its reaction with cysteine-thiols. For example, the rate constant of the reaction of the zinc-thiolate center of alcohol dehydrogenase with $\mathrm{ONOO}$ is $5.2 \times 10^{5} \mathrm{M}^{-1} \mathrm{~s}^{-1}(22)$. The rate constant for the reaction of cysteine thiols with $\mathrm{ONOO}^{-}$is $500 \mathrm{M}^{-1} \mathrm{~s}^{-1}$ (49). The faster reaction with $\mathrm{ONOO}^{-}$is due to zinc, which has the highest chargeto-atomic radius ratio of any element and maintains partial cationic character even in a tetracoordinate complex such as a zinc-thiolate cluster. Thus, zinc will attract anionic oxidants, resulting in the loss of zinc followed by disulfide bond formation within the metal binding site.

Increased eNOS-derived $\mathrm{O}_{2}$-- $^{-}$and $\mathrm{ONOO}^{-}$have been demonstrated in cultured endothelial cells exposed to elevated glucose (39), and in diabetic animals $(42,43)$ and human blood vessels $(41,44,45)$. In addition, there is evidence for dysfunctional, uncoupled eNOS in experimental and clinical studies showing that the administration of $\mathrm{BH}_{4}$ improved endothelial dysfunction in diabetes $(44,45)$. In the present study, treatment of BAECs either with $\mathrm{ONOO}^{-}$or with 3 days of exposure to elevated glucose resulted in loss of zinc, uncoupling of eNOS, and increased $\mathrm{O}_{2}^{--}$release similar to that seen with recombinant eNOS exposed to OONO-. The effects of elevated glucose were prevented by SODPEG or L-NAME, giving credible evidence that endogenous generation of $\mathrm{ONOO}^{-}$was responsible for the effects on eNOS. In addition, we have provided evidence that $\mathrm{ONOO}^{-}$generated by endothelial cells exposed to elevated glucose increases the cellular content
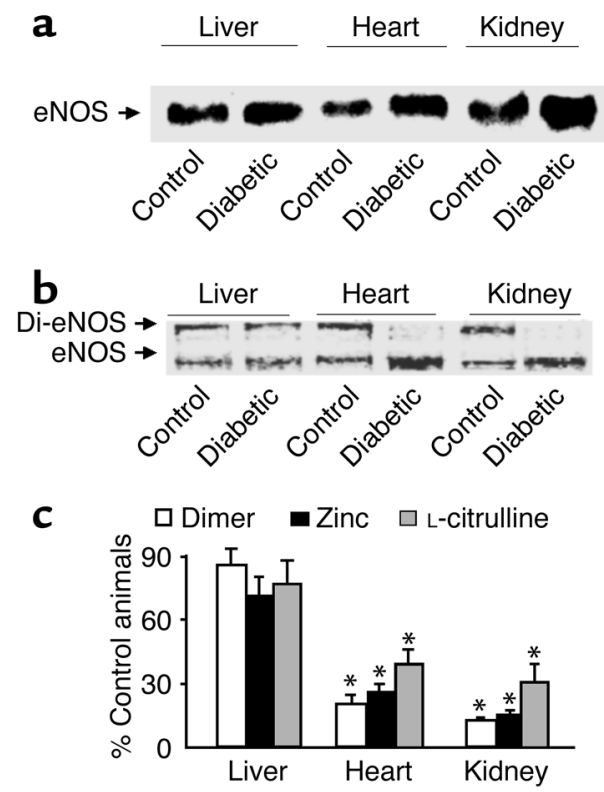

\section{Figure 6}

Increased eNOS monomer and decreased eNOS dimer and zinc content are associated with decreased eNOS activity in tissues of diabetic LDLR-KO mice. (a) Representative Western blot of eNOS protein in tissues from control and diabetic LDLR-KO mice. Tissue homogenate proteins were separated by normal-temperature SDS-PAGE under reducing conditions, blotted, and stained with a polyclonal antibody against eNOS. Blot shown is representative of three independent experiments. (b) Increased eNOS monomers are accompanied by a decrease in eNOS dimer in the tissues obtained from diabetic LDLR-KO mice. The eNOS protein in control or diabetic tissue homogenates was purified, separated by low-temperature SDS-PAGE under reducing conditions (without boiling), and detected by Coomassie staining. Results shown represent four independent experiments. (c) Decreased zinc content is associated with inhibition of NO synthesis and decreased eNOS dimer in diabetic LDLR-KO mice. The zinc content of eNOS from diabetic LDLR-KO mouse tissues was expressed as a percentage of that in normoglycemic control LDLR-KO animals. L-citrulline formation was determined in homogenates from control and diabetic animals and expressed as a percentage of that in tissues from control animals $\left(n=7,{ }^{*} P<0.05\right)$. The assay was performed as described in Methods, and the rates of L-citrulline formation were determined to be $47 \pm 11$, $56 \pm 19$, and $43 \pm 16 \mathrm{pmol} / \mathrm{mg} / \mathrm{min}$ in liver, heart, and kidneys, respectively, of normoglycemic control LDLR-KO animals. 
of 3-nitrotyrosine and inactivates prostacyclin synthase through tyrosine nitration of that enzyme. In this study, the increase in 3-nitrotyrosine content of prostacyclin synthase was prevented by treating BAECs grown in elevated glucose with SOD-PEG or L-NAME. This suggests that the $\mathrm{ONOO}^{-}$generated by eNOS has deleterious effects not only on eNOS itself, but also on other cellular proteins. Therefore, disruption of the zinc-thiolate cluster of eNOS by $\mathrm{ONOO}^{-}$might be an important mechanism in the development of vascular disease, which is enhanced by diabetes, as demonstrated in this study in diabetic mice deficient in LDLR.

\section{Acknowledgments}

We thank Karlene Maitland and Shinqin $\mathrm{Xu}$ for technical assistance with LDLR-KO mice studies. This work was supported by grants from the American Heart Association, the Juvenile Diabetes Foundation International (JDFI), and by NIH-JDFI grant PO1 HL-96005-05.

1. Marletta, M.A. 1993. Nitric oxide synthase. Structure and mechanism. J. Biol. Chem. 268:12231-12234.

2. Michel, T., and Feron, O. 1997. Nitric oxide synthases: which, where, how, and why? J. Clin. Invest. 100:2146-2152.

3. Nathan, C., and Xie, Q.W. 1994. Regulation of biosynthesis of nitric oxide. J. Biol. Chem. 269:13725-13728.

4. Raman, C.S., et al. 1998. Crystal structure of constitutive endothelial nitric oxide synthase: a paradigm for pterin function involving a novel metal center. Cell. 95:939-950.

5. Ludwig, M.L., and Marletta, M.A. 1999. A new decoration for nitric oxide synthase - a $\mathrm{Zn}(\mathrm{Cys}) 4$ site. Structure Fold Des. 7:R73-R79.

6. Li, H., et al. 1999. Crystal structures of zinc-free and -bound heme domain of human inducible nitric-oxide synthase. Implications for dimer stability and comparison with endothelial nitricoxide synthase. J. Biol. Chem. 274:21276-21284.

7. Leber, A., et al. 1999. Characterization of recombinant human endothelial nitric-oxide synthase purified from the yeast Pichia pastoris. J. Biol. Chem. 274:37658-37664.

8. Hemmens, B., Goessler, W., Schmidt, K., and Mayer, B. 2000. Role of bound zinc in dimer stabilization but not enzyme activity of neuronal nitricoxide synthase. J. Biol. Chem. 275:35786-35791.

9. Martasek, P., et al. 1998. The C331A mutant of neuronal nitric-oxide synthase is defective in arginine binding. J. Biol. Chem. 273:34799-34805.

10. Miller, R.T., Martasek, P., Roman, L.J., Nishimura, J.S., and Masters, B.S.S. 1997. Involvement of the reductase domain of neuronal nitric oxide synthase in superoxide anion production. Biochemistry. 36:15277-15284.

11. Miller, R.T., Martasek, P., Raman, C.S., and Masters, B.S. 1999. Zinc content of Escherichia coli- expressed constitutive isoforms of nitric-oxide synthase: enzymatic activity and effect of pterin J. Biol. Chem. 274:14537-14540.

12. Scheele, J.S., et al. 2001. Kinetics of CO and NO ligation with the Cys $331 \rightarrow$ Ala mutant of neuronal nitric oxide synthase. J. Biol. Chem. 276:4733-4736.

13. Beckman, J.S. 1996. Oxidative damage and tyrosine nitration from peroxynitrite. Chem. Res. Tox icol. 9:836-844.

14. Beckman, J.S., and Koppenol, W.H. 1996. Nitric oxide, superoxide, and peroxynitrite: the good, the bad, and ugly. Am. J. Physiol. 271:C1424-C1437.

15. Vasquez-Vivar, J., et al. 1999. Tetrahydrobiopterin-dependent inhibition of superoxide generation from neuronal nitric oxide synthase. J. Biol. Chem. 274:26736-26742.

16. Vasquez-Vivar, J., et al. 1998. Superoxide generation by endothelial nitric oxide synthase: the influence of cofactors. Proc. Natl. Acad. Sci. USA. 95:9220-9225

17. Laursen, J.B., et al. 2001. Endothelial regulation of vasomotion in apoE-deficient mice: implications for interactions between peroxynitrite and tetrahydrobiopterin. Circulation. 103:1282-1288.

18. Xia, Y., Tsai, A.L., Berka, V., and Zweier, J.L. 1998 Superoxide generation from endothelial nitricoxide synthase. A $\mathrm{Ca}^{2+} /$ calmodulin-dependent and tetrahydrobiopterin regulatory process J. Biol. Chem. 273:25804-25808.

19. Zou, M.H., Martin, C., and Ullrich, V. 1997. Tyrosine nitration as a mechanism of selective inactivation of prostacyclin synthase by peroxynitrite. Biol. Chem. 378:707-713.

20. Zou, M.H., et al. 2000. Rapid reactions of peroxynitrite with heme-thiolate proteins as the basis for protection of prostacyclin synthase from inactivation by nitration. Arch. Biochem. Biophys. 376:149-155.

21. Castro, L., Rodriguez, M., and Radi, R. 1994 Aconitase is readily inactivated by peroxynitrite, but not by its precursor, nitric oxide. J. Biol. Chem. 269:29409-29415.

22. Crow, J.P., Beckman, J.S., and McCord, J.M. 1995 Sensitivity of the essential zinc-thiolate moiety of yeast alcohol dehydrogenase to hypochlorite and peroxynitrite. Biochemistry. 34:3544-3552.

23. Maret, W., and Vallee, B. 1998. Thiolate ligands in metallothionein confer redox activity on zinc clusters. Proc. Natl. Acad. Sci. USA. 95:3478-3482.

24. Jacob, C., Maret, W., and Vallee, B. 1998. Control of zinc transfer between thionein, metallothionein, and zinc proteins. Proc. Natl. Acad. Sci. USA. 95:3489-3494.

25. Knapp, L.T., and Klann, E. 2000. Superoxideinduced stimulation of protein kinase $C$ via thiol modification and modulation of zinc content J. Biol. Chem. 275:24136-24145.

26. Pollock, J.S., et al. 1991. Purification and characterization of particulate endothelium-derived relaxing factor synthase from cultured and native bovine aortic endothelial cells. Proc. Natl. Acad. Sci. USA. 88:10480-10484.

27.Zou, M.H., and Ullrich, V. 1996. Peroxynitrite formed by simultaneous generation of nitric oxide and superoxide selectively inhibits bovine aortic prostacyclin synthase. FEBS Lett. 382:101-104.

28. Zou, M.H., Shi, C., and Cohen, R.A. 2002. High glucose via peroxynitrite causes tyrosine nitration and inactivation of prostacyclin synthase that is associated with TP receptor-mediated apoptosis and adhesion molecule expression in cultured human aortic endothelial cells. Diabetes. 51:198-203.

29.Zou, M.H., Jendral, M., and Ullrich, V. 1999. Prostaglandin endoperoxide-dependent-vasospasm in bovine coronary arteries after nitration of prostacyclin synthase. Br. J. Pharmacol. 126:1283-1292.
30. Bernier, S.G., Haldar, S., and Michel, T. 2000 Bradykinin-regulated interactions of the mitogen-activated protein kinase pathway with the endothelial nitric oxide synthase. J. Biol. Chem. 275:30707-30715.

31. Cayatte, A., et al. 2001. S17834, a new inhibitor of cell adhesion and atherosclerosis that targets NADPH oxidase. Arterioscler. Thromb. Vasc. Biol. 21:1577-1584.

32. Tang, Z., Wasserloos, K., Croix, C.M., and Pitt B.R. 2001. Role of zinc in pulmonary endothelial cell response to oxidative stress. Am. J. Physiol. Lung Cell. Mol. Physiol. 281:L243-L249.

33. Massey, V. 1994. Activation of molecular oxygen by flavins and flavoproteins. J. Biol. Chem. 269:22459-22462.

34. Pasquet, J.P.E.E., Zou, M.H., and Ullrich, V. 1996. Inhibition of nitric oxide synthase by peroxynitrite. Biochimie. 78:785-791.

35. Nagano, T., Hirano, T., and Hirobe, M. 1989. Superoxide dismutase mimics based on iron in vivo. J. Biol. Chem. 264:9243-9249.

36. Moon, J.O., Park, S.K., and Nagano, T. 1998. Hepatoprotective effect of Fe-TPEN on carbon tetrachloride induced liver injury in rats. Biol. Pharm. Bull. 21:244-288.

37. Katusic, Z.S. 2001. Vascular endothelial dysfunction: does tetrahydrobiopterin play a role? Am.J. Physiol. 281:H981-H986.

38. Sokolovsky, M., Riordan, J.F., and Vallee, B.L. 1966. Tetranitromethane. A reagent for the nitration of tyrosyl residues in proteins. Biochemistry. 5:3582-3589.

39. Cosentino, F., Hishikawa, K., Katusic, Z.S., and Luscher, T.F. 1997. High glucose increases nitric oxide synthase expression and superoxide anion generation in human aortic endothelial cells. Circulation. 96:25-28.

40. Hink, U., et al. 2001. Mechanisms underlying endothelial dysfunction in diabetes mellitus. Circ. Res. 88:F14-F22.

41. Kossenjans, W., Eis, A., Sahay, R., Brockman, D., and Myatt, L. 2000. Role of peroxynitrite in altered fetal-placental vascular reactivity in diabetes or preeclampsia. Am. J. Physiol. Heart Circ. Physiol. 278:H1311-H1319.

42. Shinozaki, K., et al. 1999. Abnormal biopterin metabolism is a major cause of impaired endothelium-dependent relaxation through nitric oxide/O2-imbalance in insulin-resistant rat aorta. Diabetes. 48:2437-2445.

43. Shinozaki, K., et al. 2000. Oral administration of tetrahydrobiopterin prevents endothelial dysfunction and vascular oxidative stress in the aortas of insulin-resistant rats. Circ. Res. 87:566-573.

44. Heitzer, T., Krohn, K., Albers, S., and Meinertz, T 2000. Tetrahydrobiopterin improves endothelium-dependent vasodilation by increasing nitric oxide activity in patients with Type II diabetes mellitus. Diabetologia. 43:1435-1438.

45. Pieper, G.M. 1997. Acute amelioration of diabetic endothelial dysfunction with a derivative of the nitric oxide synthase cofactor, tetrahydrobiopterin. J. Cardiovasc. Pharmacol. 29:8-15.

46. Xia, Y., and Zweier, J.L. 1997. Superoxide and peroxynitrite generation from inducible nitric oxide synthase in macrophages. Proc. Natl. Acad. Sci. USA. 94:6954-6958.

47. Huhmer, A.F.R., Nishida, C.R., Ortiz de Montellano, P.R., and Schoneich, C. 1997. Inactivation of inducible nitric oxide synthase by peroxynitrite. Chem. Res. Toxicol. 10:618-626.

48. Huhmer, A.F.R., Gerber, N.C., Ortiz de Montellano, P.R., and Schoneich, C. 1996. Peroxynitrite reduction of calmodulin stimulation of neuronal nitric oxide synthase. Chem. Res. Toxicol. 9:484-491.

49. Arteel, G., and Sies, H. 1999. Protection against peroxynitrite. FEBS Lett. 445:226-230. 